\title{
Portuguese nursing: history of the life and activism of Maria Augusta Sousa
}

\author{
A enfermagem portuguesa: história de vida e militância de Maria Augusta Sousa \\ La enfermería portuguesa: historia de vida y militancia de Maria Augusta Sousa
}

Deybson Borba de Almeida', Gilberto Tadeu Reis da Silva², Paulo Joaquim Pina Queirós ${ }^{3}$, Genival Fernandes de Freitas ${ }^{4}$, Aline Di Carla Laitano², Sirléia de Sousa Almeida², Victor Porfirio Ferreira Almeida Santos ${ }^{2}$

How to cite this article:

Almeida DB, Silva GTR, Queirós PJP, Freitas GF, Laitano ADC, Almeida SS, et al. Portuguese nursing: history of the life and activism of Maria Augusta Sousa. Rev Esc Enferm USP. 2016;50(3):495-501. DOI: http://dx.doi.org/10.1590/S0080-623420160000400017

${ }^{1}$ Universidade Estadual de Feira de Santana, Feira de Santana, BA, Brazil.

${ }^{2}$ Universidade Federal da Bahia, Salvador, BA, Brazil.

${ }^{3}$ Escola Superior de Enfermagem de Coimbra, Coimbra, Portugal.

${ }^{4}$ Universidade de São Paulo, Escola de Enfermagem, Departamento de Orientação Profissional, São Paulo, SP, Brazil.

\begin{abstract}
Objective: To analyze the history of the life and activism of Portuguese nurse Maria Augusta Sousa. Method: Sousa's life story was obtained by means of semi-structured interviews with Sousa as the oral source of data. N Vivo qualitative research software was used for data analysis. Content analysis focused on thematic analysis based on the theoretical and philosophical ideas of Michel Foucault, in particular, power and techniques of the self. Results: Alienation and political participation were revealed as pertinent issues. In techniques of production of activist subjects, the following were highlighted: the importance of the review of formal education; actions of involvement with the world, society and the profession; and finally, techniques of the self, techniques of constitution of activist subjects, professional identity and way of being. Conclusion: The constitution of the nurse Maria Augusta Sousa as an activist came about through questioning of how to be, education in the context of her family, and political engagement in Catholic Youth. This impacted her trajectory of contributions to Portuguese nursing, as expressed in the following achievements: the integration of nursing training into higher education; the creation of the Regulation of Nurses Professional Practice; and implementation of the Order of Nurses.
\end{abstract}

\section{DESCRIPTORS}

History of Nursing; Education, Nursing; Politcs. 


\section{INTRODUCTION}

Since the 1970s, due to its increasing complexity, the profession of nursing in Portugal has undergone major transformations, with the aim of recognizing and qualifying the activities of the profession and thereby improving quality of care $^{(1)}$. Among these changes, the following are notable: professional training at a single level, and the end of education of nursing assistants (1975); unification of the career (1981); integration of nursing training into the national education system (1988); creation of the Regulation of Nurses Professional Practice (1996); implementation of the Order of Nurses (OE) (1998); and licensing as initial training (1999).

These changes were made possible by the political organization of nurses into trade unions, in particular, the Union of Nurses of the South Zone and Autonomous Region of the Azores. Later, in 1988, because of its presence and activism at the national level, this union was renamed the Union of Portuguese Nurses.

The nurse Maria Augusta Sousa coordinated this union and was part of the OE deployment team. In her first term from 1999 to 2003, Sousa was vice president. She then served two consecutive terms as president (2004 to 2007 and 2008 to 2011). Thus, Sousa held office in the OE for 12 of the 17 its years of existence.

In the present article, the authors explore Sousa's life history during the last two decades, her protagonism in the face of the political struggles and conflicts of the profession, and the history of Portuguese nursing, with analysis supported by the political dimension of nurses.

In comparative terms, with regard to the production of knowledge about the life history of individuals in nursing who contributed to reconfiguring the profession, the authors drew on the study of Brazilian nurse Maria Rosa Sousa Pinheiro, whose life path consolidated a new representation of the feminine in social and work spheres ${ }^{(2)}$.

Given the lack of studies on the topic in question (the authors found only two studies related to the $\mathrm{OE}$ in the Online Health Library), and taking into account the current precariousness of labor conditions in Portugal, an examination of Sousa's contribution to the topic is relevant.

From this perspective, in their professional everyday life, Portuguese nurses experience work overload, low compensation, conflicts with hegemonic medical authority and conflicts with support staff in hospitals. The Portuguese State is the largest employer of nurses, and in a context of job insecurity and lack of employment opportunities, many professionals are forced to seek work in other European countries.

One recent study sought to understand skilled immigration, focusing on medicine and nursing, and found that the high flow of immigrants was driven by job opportunities and better working conditions. The study also highlighted the importance of institutional roles, professional associations and unions, and the weakness of policies directed toward resolving this problem ${ }^{(3)}$.

In this sense, the importance of a discussion that articulates Sousa's life story and political activism is evident, because it generates perspectives on the training of nurses and the future of the profession. Historical studies are an opportunity to increase consciousness of and action on the needs of the profession, because such studies entail critical and reflective knowledge, in this case about a politics of health care that can produce more humane and ethical care in several ways.

Based on Foucault's concept of constitution of subjects, the authors began their research with the following questions: How do nurses travel down the paths of alienation and participation? How was Maria Augusta Sousa constituted as an activist and nurse? Which formative fields contributed to her trajectory as an activist? What techniques of production of subjects exist in her life story? The objective of the study was to analyze the constitution of Sousa as an activist in nursing.

\section{METHOD}

This was a study of Sousa's life history, with a biographical focus characterized by her creative movement, which produces meaning when outlined as the source of new knowledge. The authors go on to analysis of the dimension of the status of the narrated subject, this status being transformed as a result of who listens.

It is important to note that the philosophical framework that supported analysis of the constitution of subjects was based on the work of Michel Foucault. The theoretical aspects of techniques of the self were divided into four main groups: (1) techniques of production, which enable the production, transformation or manipulation of things; (2) techniques of sign systems, which enable the use of signs, meanings, symbols or meaning; (3) techniques of power, which determine the conduct of individuals and submit them to certain ends or domination, and objectify the subject; and (4) techniques of the self, which enable individuals to perform, by their own means or with the help of others, a number of operations on their own bodies, souls, thoughts, behavior and ways of being, in order to transform them and achieve certain states of happiness, purity, wisdom, perfection or immortality ${ }^{(4)}$.

Maria Augusta Sousa was born in 1947 and participated in the Young Catholic Workers (JOC) and the International Christian Youth Workers. Sousa graduated in nursing from the Artur Ravara College of Nursing in 1968 , and specialized in mental health nursing and psychiatry in 1992. She worked as a nurse at São José and Santo António dos Capucho hospitals, and had a decisive role in the drafting of the Regulation of Nurses Professional Practice and the creation and implementation of the Order of Nurses (OE), of which she was president for eight years and vice president for four years. Sousa was a member of the Executive Committee of the European Forum of National Nursing and Midwifery Associations and the Governing Council of the International Council of Nurses (ICN).

The present study was funded by the Coordination for the Improvement of Higher Education Personnel, and carried out with Sousa, the object and only participant in this study, in Coimbra, Portugal, during the primary researcher's doctoral degree studies. Data were collected in 
October 2015 by a semi-structured interview. The interview was recorded after the participant authorized the interview and signed a free and informed consent form and a letter authorizing use of the interview.

The duration of the interview was 2 hours and 42 minutes; it was then transcribed and transcreated. Analysis of the interview was conducted from October 28 to November 4, 2015. NVivo 10 software was used to organize and tabulate the oral history, which had been transformed from oral to written data. This software enables the exploration of in-depth interviews and organization and analysis of semistructured interviews.

For data analysis, the authors selected the method of content analysis, because it is a set of techniques for analysis of communications that utilizes systematic procedures and objectives to describe the content of the messages and obtain indicators (quantitative or not) that enable the inference of knowledge relative to the conditions of production/reception (inferred variables) of the messages ${ }^{(5)}$. Data analysis consisted of the following steps: isolation of record units; enumeration based on the frequency, on the treatment of the results and on interpretation.

Categorization of the data was based on record units and manifest content, which enabled identification, over the life of the study participant, of acts that connected and were interrelated.

As for categories of analysis, they were expanded into categories and subcategories, which in the software are called nodes and internal nodes, respectively. In the category of techniques of power, the authors obtained the technical subcategories of participation and alienation. In the category of techniques of production, the authors obtained the subcategories formal education and actions of involvement with the world, society and the profession of nursing. Finally, in the category of techniques of the self, the researchers obtained the subcategories professional identity and mode.

The present study complied with the ethical principles of research proposed by National Health Council Resolution No. 466/2012, and was submitted to Plataforma Brasil and approved by the Research Ethics Committee (CAAE: 28775614.2.0000.5531) under opinion number 663.359.

\section{RESULTS}

The study results converged to respond to the central research questions, because the researchers wanted to analyze the constitution of activist subjects, anchored in the theoretical and philosophical framework of Foucault and the qualitative analysis software.

Analysis with Nvivo research software enabled the authors to find the categories (referred to as "nodes" by the software program) and subcategories (referred to as "subnodes" by the software) of analysis.

The first analytical category, or node, was composed of the techniques or devices of power, present in the phenomenon studied, that being the life story of Maria Augusta Sousa and her constitution as an activist subject in Portuguese nursing.
SUB-NODE: ALIENATION AND ITS IMPLICATIONS FOR WORK IN NURSING

(...) [Speaking about nursing] work for everyone, disorganized work, even more so with this difficulty. The difficulty objectifies political affirmation, scientific and political participation [speaks of the triple work shift and women's work], the disorganization of time is brutal and, therefore, is the reason for not participating, and those who do not participate cannot have, cannot gain, political power. Political power is gained when one participates (...).

(...) that we have one of the most serious problems. How can we enable Portuguese nursing, believe in its value, believe in its power? (...).

(...) So, nursing has a lot of trouble getting outside the walls [the workload of nurses was increased to 40 hours by government decree], we have a 40-hour work week. Nurses need to struggle, raise the flag and be able to get there. We are living in a time of removal of social rights; it is a serious problem in Portuguese society. It is not just the problem of nurses; it is of Portuguese society. So, how can we change this if nurses do not participate, are not normally in the areas of debate, and are separated from this? (...).

(...) [Speaking about nursing]We have closed logic [refers to non-recognition of global problems by nursing], closed logic in the overall picture, things can only be solved globally, they are not resolved in the group [specifically nursing].

(...) [Talking about delegation of care activities to operational technicians] that nurses do not have an accurate picture of their tasks (private), the responsibilities for care, sometbing failed in our discussion [referring to the discussion promoted by the trade unions on the role of nurses].

(...)Professional status was something that came from the 1970s. We had several meetings to discuss what the statute had to contain, which required collective participation. What would the statute need to contain? This is because there were those who wanted to put in the statute whether nurses would place the water tray or not place the water tray (...).

(...) The statute says that the interventions of nurses are autonomous and interdependent. But this was the most difficult question of all, some wanted the nursing interventions to be autonomous, interdependent and dependent. And this was the war. I'm talking about the cream of nursing, some thought like that (...).

From the above statements, the authors perceived that nursing, as a field of work, has difficulties in the field of political statement due to precarious working conditions, devaluing the category's power to make demands, failure of these professionals to think about the world as a whole, and weakness in nurses'understanding of their role in health care organizations.

\section{SUB-NODE: POliticAl PARTICIPATION, PRODUCTION AND IMPACT}

(...) Political power is gained when you participate. One does not win just by having a party, it is won because you actively participate in things. In this mix, you meet people, people count on us and we rely on others (...). 
(...) [Speaking of training of nursing assistants to acquire nursing degrees] between 1976 and 1981, virtually all nursing assistants were trained. I'm not kidding, a spectacular national cooperation among unions, institutions, training centers, and schools. Even with all the differences that were not addressed, things continued in any case, the movement generated this (...).

(...) [Talking about the Nursing Congress in '73] organized by the unions and the association of nurses, the Portuguese association and Catholic association. [where a political project for the profession was discussed] four fundamental aspects: single career, higher education training, statute and order. This was everything we did in those two decades. The 1980s was marked by all these steps (...).

(...) It is part of the role of the union to discuss with the nurses to steer things that we have done or tried to do (...).

(...) [On the discussions of the statute]We held several assemblies from the north to the south of the country to discuss these issues, in all the districts. We started out by saying that each one will say what they think has to be put in the statute, even if it will be putting the water tray, everything came out at the beginning of each meeting. Working groups were formed, nurses participated, and in the end there was more coherent direction of what should be in the statute, which should have principles (...).

(...) [Speaking of the most active union to establish the Order of Nurses] It was my union [of which she was president] (...).

(...) It was the way to have a discussion with colleagues about what was important. Usually we went to work, then we would meet with all those who wanted to go... We argued with a security guard even in terms of power and counter-power, [however, in discussions with the government] we could not give in easily. To give in we had to consult colleagues. This sometimes created a lot of confusion with our colleagues in the union (...).

[On the first edition of the Leadership for Change Program, sponsored by the OE and the ICN] (...) The colleagues who participated had a project coordinated by an American coordinator. Stefani made the connection with our colleague, who was responsible for the program here. These 20 colleagues participated in a group and studied, on their own, a program that is 2 years, they were defining intervention projects in the local community, to then evaluate what they were doing (...) I think it was very interesting, we had the participation of entities that the colleagues were part of, that represented the institutions, developed protocols to put the projects into action. And it was interesting for recognition of the profession and the Order itself. The Order itself will be recognized (...).

In the second category, techniques of production of activist subjects, the following sub-nodes were indicated:

\section{SUB-NODE: ACTIONS OF INVOLVEMENT WITH THE WORLD, SOCIETY AND PROFESSION}

(...) Before getting into nursing I was already involved in the youth movement, the youth of the Catholic Church. This was in the fascist period, the movement against the government by the Catholic Church movement (...).

(...) The Catholic youth had a methodology, and I think it still has, called "vision", which was very important. We had this little game of ping pong, but we also had topics that arose in the group discussion, that we took home to reflect on and bring the next week. We sought to discuss various topics such as social injustice, we had to do this every week (...).

(...) It was at the end of the course, already at the end of the course. And there was a serious problem, floods, it was brutal. Floods that resulted in many people being homeless. I was doing psychiatry at that point, I remember perfectly. And people came to me who knew the JOC, came to me, while I was in school. And they came to me because of the history of floods, to see if I wanted to get into a group to go to a neighborhood to help, to manage what was happening. I said, "Well, if it is for this, I will go". (...).

[Speaking of projects managed by the OE] (...) The same thing in the design of mobile libraries, I have no idea how it is (...) nothing more than that, a chest with nursing documentation, for circulation in countries where the official language is Portuguese, such as Angola, Mozambique, Guinea, São Tome and Cape Verde, and later Timor. An update, which can be walked from one place to another, and therefore can be in one place at one time and another place at another time. It also allows for growth of this component in areas of difficult access, and can serve as an instrument of nursing knowledge (...).

\section{SUB-NODE: FORMAL EDUCATION AND ITS CONTRIBUTION TO THE CONSTITUTION OF ACTIVIST SUBJECTS}

(...) I think that nursing education did not help this [referring to political activism]. On the contrary, it was education heavily oriented toward submission, in order to ensure everything was in order, for everyone to stay in line, so I think that nursing did not increase my activism. It was my previous career in social science that gave me this activism at the level of social science that I reached, this allowed me to face some aspects that were not usually faced by colleagues. The behavior of all the professors was very authoritarian, only one or two were different. At the time, nursing was always linked to the religious order, influenced by the Catholic movement, which had a very important role in the training. It was here, that is, in the same training [referring to technical and nursing procedures], actions outside of the sets were not done, which did not allow nursing to evolve (...).

(...) At the time, they said that because of my political dimension, I could not be a nurse, that I was an agitator, threats were even made, everything was done so that I did not finish the course (...).

(...) Everything should be in secret, and there should be no confrontation [referring to the perspectives of other people], several colleagues said that we could not fight, we should not confront (...).

Finally, in the third category of techniques of the self, the sub-nodes identified were professional identity and way of being of the activist in the study. This reveals initial 
ignorance of the profession; however, with development of the course, there is a meeting with a vocation and consequent professional satisfaction. It also shows the values of appreciation of the work and educational dialogue, with openness to discussing the dilemmas of society and the implications for social justice. There are records of confrontations on matters of tradition and acts of liberation as against what was imposed.

\section{SUB-NODE: PROFESSIONAL IDENTITY WITH NURSING}

(...) I think I got into nursing because I did not want to work in an office. I would not go for any of that. I went into nursing more for what I did not want than what I wanted. I already had it in my head that I did not want a profession that would keep me in an office, for me this was separation. I wanted a job related to society, but did not want to be a teacher, for me this did not work (...).

(...) I like being a nurse, I like the profession, and I think the profession has a very important social role, which unfortunately is not recognized (...).

(...) Me joining the union was not in vain, no, I joined the union because I loved it (...).

\section{SUB-NODE: WAYS OF BEING AN ACTIVIST IN NURSING}

[Speaking about learning her family's values] (...) It was important to have some work experience, it was an essential, important issue. So there was a sense from my mother and my father, above all, that work is a central issue (...).

[Speaking about learning her family's values] (...) Things were not camouflaged, if there was no money, there was no money, and that was that, but we never felt this as something unhappy, you know? (...).

(...) my mother had a very faithful notion of justice, very present, my father as well (...).

(...) to decide who would continue their studies, because we did not have the conditions for everyone to continue. [Speaking of her three sisters] Because we did not have the conditions for all four kids to study, my older sister did not want to study, I wanted to, the other also did not want to. So, it was me, she could only support two, no more than two (...).

[Talking about the strategy for getting her parents to accept that she would do the nursing course] (...) I arranged a ruse, I asked the schools to send the invitations to study nursing to my house. They sent the missionaries of Mary, my mother questioned why I received so many invitations. I said it must be because they sent them to everyone. It went on for a long time. My father told me I was not going to study. I told him I would not discuss this at home anymore, when I finished high school, I would do it. I think be took that seriously (...).

(...) [On an injustice committed against a colleague at school] I defended the colleague, this is wrong, there were even threats [made against me], everything was done so that I did not finish the course, I remember I graduated (...).
[Talking about the manager's invitation to the class of newly qualified nurses about which area they wanted to work in, whether in management or care] (...) I was in this group of five, this group of five [who opted for care], it was, at the bottom, to break with the establishment (...).

\section{DISCUSSION}

Initially, the researchers realized that, from a hermeneutic and dialectical perspective, the analysis categories are opposed within the highlighted axes, and this aspect conforms to the internal reliability of the study. Alienation is the inverse of political participation, formal education is configured as an aspect, in a predominant manner, limiting the phenomenon, while involvement with social issues figured as something that revealed and formed the activist subject.

Her life history also enabled the configuration of analytical categories based on professional identity and ways of being of the interviewee, in Foucault's conception of what constitutes an activist.

In the first dimension of the results, the political weakness of nursing can be marked by questions of technical training with a strong religious influence, which is related to the discussion of gender, i.e., the social role of women and their social construction.

The alienation of the worker is understood, in its product, as something linked to lack of knowledge of the professional in relation to that which is, which makes, and the power she has. This implies not only that the work becomes an object and takes on an external existence, but that it exists independently, outside the subject, it is foreign to her, and so it becomes an autonomous power, a hostile and antagonistic force ${ }^{(6)}$.

Thus, a vicious and interrelated circle is perceived: the more precarious working conditions become (which is currently happening in Portugal, with an increase in weekly working hours and reduction of wages and bonuses), the more alienation is observed. Because the work of individuals turns into survival, spaces for political participation are not found.

With poor working conditions, nursing workers have too little time, hampering becoming aware of the world and perceiving power games and existing expropriation in the social web. From the point of view of contemporary social thought, this is founded on the assertion that time is an element that makes possible the knowledge and exercise of reason ${ }^{(7)}$.

This political weakness is also related, in a global sense, to historical aspects of Portugal.There was a long period between the military revolution of 1926 and the New State and the Revolution of April 25, 1974.Known as the Carnation Revolution, it was characterized by the omnipresence of political and police repression (International Police for the Defense of the State), which resulted in half a century of censorship of the media and entertainment, rigorous suppression of fundamental freedoms, special courts and prisons whose main summit was the secret police, and systematic violation of the rights of citizens ${ }^{(8)}$. 
However, there are prospects for change arising from the mobilization of workers, together with representative bodies (unions) and the involvement of nursing schools, to enable training that is more engaged with ethical and political aspects of the profession and global issues of social movements.

Regardless, when it comes to techniques of power, participation is understood here as a device of activism and power. Sousa's political participation in Portuguese nursing was relevant, both as a coordinator of the union and as a creator of the Regulation of Nurses Professional Practice and Order of Nursing. She says that it was one time when the professional category of nursing believed in change and built it, and that political activism is made by action, that is, the more one participates in class movements, the more one engages politically.

Among these processes of change, the following can be highlighted: the delimitation of a single level of training for nursing, the single career; the inclusion of nursing training in higher education; the Regulation of Nurses Professional Practice; and the Order of Nursing. The union that Sousa coordinated had the leading role in these changes. The organization then changed, due to its representative capacity, into the Union of Portuguese Nurses.

Also important at the time during which Sousa was president of the $\mathrm{OE}$ was the projects implemented, because they were involved with changes in and scientific and political development of nurses, as well as the internationalization of Portuguese nursing.

In this sense, the literature indicates that activism emerges in people's lives as a possible way to be a subject, to be what one is. Stories of people who developed political activism show that the major motivation for activism is a sense of social justice, in which social and professional movement seeks a territory where change is possible ${ }^{(9)}$.

Political activism is clear in the trajectory of the nurse's life, here understood as an activity that constitutes a political form, engaged and critical, in which actions focused on the political awareness of the population are developed, seeking to develop new values that enable people to organize and fight for the construction of a just and decent society ${ }^{(10)}$.

The political education of Maria Augusta Sousa took place outside the spaces of formal education, specifically schools. Her training as a citizen occurred in the Catholic movement, permeated by reflective practices on the world and the things around her, shown in her description of her actions when she temporarily abdicated professional issues to help the victims of a natural disaster.

In the field of professional training, moments are described that are marked by persecution and silence. Everything should always be in order, aspects of religious and military organization.

It should be noted, therefore, that the disciplinary aspects of nursing were strongly influenced by the religious institution and its implications for political activism. The authors believe that thought focused on maintaining order, in the strict sense, is fragile from a critical point of view and in its political dimension, because it is centered on hierarchy and compliance with rules that often do not have a theoretical and philosophical foundation. In Portugal, many of the schools were run by religious orders or private foundations, with education in the first part of the course focused on the domain of practice. Dexterity and manual skills were emphasized, and nurses were to show a combination of kindness, skill and obedience ${ }^{(2)}$.

The researchers noted that professional identity occurs in the very process of education. This finding is consistent with studies on this subject, which have shown that socially, the image of nurses runs through two imaginary fields: one is a mythical relationship with medicine, and the other is an imaginary feminine of submission and inferiority ${ }^{(11)}$.

Finally, the issue of the constitution of the person Maria Augusta Sousa passes through practices of participation, defense, liberty, truth and justice. Her path was marked by financial difficulties and the valuation of work as a process of overcoming economic barriers.

The results of the present study corroborate the literature, both national ${ }^{(10)}$ and international ${ }^{(12)}$, on the political dimension of the profession. It was only in 2008 , at the international level, that this dimension was understood as transversal knowing of knowledge in nursing. The present study differs from others, in that it explains the political strength of the category of nurses through their professional associations and strategies that increased the membership of the category, validating their power as a working class ${ }^{(1)}$.

The present study points to the need for review of curricula and the process of training nurses, the need to promote strategies to strengthen the representative bodies of the professional category of nursing, and the need for actions that bring together these entities at the national and global levels.

\section{CONCLUSION}

The working category of nurses moves between paths of alienation, due to the hegemonic teaching model in nursing and political participation, by the issues that emerge from the capital, such as precarious work.

The constitution of the nurse Maria Augusta Sousa as an activist occurred by way of questions on how to be, family education and her political engagement in the Catholic Youth Movement. This is reflected in her trajectory of contribution to Portuguese nursing, expressed in the following achievements: the integration of nursing education into higher education; the creation of the Regulation of Nurses Professional Practice; and the implementation of the Order of Nursing.

Finally, educational spaces were motivating factors in the participant's activism, although her education was often limited by her political expression and participation. Yet in general, Sousa configured herself as a device that produced itself, often causing change in the historical course of things and people. 
RESUMO

Objetivo: Analisar a história de vida e militância da enfermeira Maria Augusta Sousa. Método: História de vida, tendo como fonte oral a entrevista semiestruturada. $\mathrm{Na}$ análise de dados utilizou-se do software de pesquisa qualitativa Nvivo, e a análise de conteúdo com foco na análise temática e com base teórico-filosófica de Michel Foucault, em especial, o poder e as técnicas de si. Resultados: Evidenciaramse a alienação e a participação política como questões pertinentes. Nas técnicas de produção de sujeitos militantes destacam-se a importância da revisão da educação formal, dos atos de implicação com o mundo, a sociedade e a profissão, e por fim, as técnicas de si, técnicas de constituição de sujeitos militantes, a identidade profissional e o modo de ser. Conclusão: A constituição da enfermeira Maria Augusta Sousa como militante acontece por questões do modo de ser, da educação familiar e do seu engajamento político na Juventude Católica, que repercutiu em uma trajetória de contribuição para enfermagem portuguesa, expressa nas seguintes conquistas: a integração do Ensino de Enfermagem no Ensino Superior, a criação do Regulamento do Exercício Profissional de Enfermagem e a implantação da Ordem dos Enfermeiros.

\section{DESCRITORES}

História da Enfermagem; Educação em Enfermagem; Política.

\section{RESUMEN}

Objetivo: Analizar la historia de vida y militancia de la enfermera Maria Augusta Sousa. Método: Historia de vida, teniendo como fuente oral la entrevista semiestructurada. En el análisis de datos, se utilizó el software de investigación cualitativa Nvivo, y el análisis de contenido con enfoque en el análisis temático y con base teórico-filosófica de Michel Foucalt, en especial, el poder y las técnicas de sí. Resultados: Se evidenciaron la enajenación y la participación política como cuestiones pertinentes. En las técnicas de producción de sujetos militantes, se destacan la importancia de la revisión de la educación formal, los actos de implicación con el mundo, la sociedad y la profesión y, por fin, las técnicas de sí, técnicas de constitución de sujetos militantes, la identidad profesional y el modo de ser. Conclusión: La constitución de la enfermera Maria Augusta Sousa como militante sucede por temas del modo de ser, la educación familiar y su involucración política en la Juventud Católica, que repercutió en una trayectoria de contribución para la enfermería portuguesa, expresada en las siguientes conquistas: la integración de la Enseñanza de Enfermería en la Enseñanza Superior, la creación del Reglamento del Ejercicio Profesional de Enfermería y la implantación de la Orden de los Enfermeros.

\section{DESCRIPTORES}

História de la Enfermería; Educación en Enfermería; Política.

\section{REFERENCES}

1. Mendes FRP, Mantovani MF. Dinâmicas atuais da enfermagem em Portugal: a representação dos enfermeiros. Rev Bras Enferm [Internet]. 2010 [citado 2015 nov. 05];63(2):209-15. Disponível em: http://www.scielo.br/pdf/reben/v63n2/07.pdf

2. Oguisso T, Campos PFS, Santiago ES. Maria Rosa Sousa Pinheiro e a reconfiguração da enfermagem brasileira. Texto Contexto Enferm [Internet]. 2009 [citado 2015 nov. 05];18(4):643-51. Disponível em: http://www.scielo.br/pdf/tce/v18n4/05.pdf

3. Baganha MI, Ribeiro JS. Imigração qualificada no sector da saúde: as oportunidades do mercado laboral português. Rev Migrações Imigração Saúde [Internet]. 2007 [citado 2015 nov. 06];1:53-78. Disponível em: http://www.om.acm.gov.pt/documents/58428/183863/ migracoes1_art3.pdf/4c59907e-538b-4263-a11d-58aaceebb412

4. Foucault M. Tecnologias de si, 1982. Verve [Internet]. 2004 [citado 2015 nov. 05];6:321-60. Disponível em: https://pt.scribd.com/ doc/296696553/Foucault-Tecnologias-de-Si-1982

5. Bardin L. Análise de conteúdo. Lisboa: Edições 70; 2011.

6. Marx K. Manuscritos econômicos-filosóficos. São Paulo: Martin Claret; 2006.

7. Hansen GL. Espaço e tempo na modernidade. GEOgraphia [Internet]. 2000 [citado 2015 nov. 12];2(3):51-67. Disponível em: http://www. uff.br/geographia/ojs/index.php/geographia/article/viewArticle/29

8. Rosa F. Salazar e o poder: a arte de saber durar. Lisboa: Tinta da China; 2012.

9. Baltazar B. Os encontros e desencontros da militância e da vida cotidiana. Psic Teor Pesq [Internet]. 2004 [citado 2015 nov. 07];20(2):18390. Disponível em: http://www.scielo.br/pdf/ptp/v20n2/a11v20n2.pdf

10. VinadéTF, Guareschi PA. Inventando a contra-mola que resiste: um estudo sobre a militância na contemporaneidade. Psicol Soc [Internet]. 2007 [citado 2015 dez. 07];19(3):68-75. Disponível em: http://www.scielo.br/pdf/psoc/v19n3/a11v19n3.pdf

11. Prestes FC, Beck CLC, Silva RMD, Simon BS, Prochnow AG. Construção da identidade profissional da enfermagem: revisão de literatura [Internet]. Brasília: Associação Brasileira de Enfermagem; 2004 [citado 2015 dez. 02]. Disponível em: http://www.abennacional.org. br/2SITEn/Arquivos/N.037.pdf

12. Carper B. Fundamental patterns of knowing in nursing. ANS Adv Nurs Sci. 1978;1(1):12-23. 